\title{
China's Views of History: The Prospect of Changing Self-Image
}

Jie LIU

\begin{abstract}
If we consider the discussions over the developmental models in the context of domestic politics and foreign relations in China, the question of what kind of historical perspective is the basis for China's state-building can be considered as a purely domestic issue. As a consequence, the nature of self-image that China is currently articulating based on its historical views is decisively important when considering the near future of the country. This article suggests that the prospect of China's view of history can be analyzed by understanding how China views the period of Republic of China (ROC) as a pre-revolutionary history.
\end{abstract}

\section{Keywords}

Self-image, civilization-based view of history, revolutionary view of history, Republic of China

\section{Introduction}

More than thirty years of reform and opening-up have transformed China from a social-class-based society to an economic-class-based society, and "pluralization" has become frequently used as an expression in describing the transforming Chinese society. The economic growth that was even called "miraculous" has afforded great possibilities to the Chinese people who desire affluence. On the other hand, however, due to the accumulation of internal social discontent and growing frictions with international society, China has become a country that is much more difficult to predict than it has traditionally been.

A sober analysis of the reality over the of politics, society, economy of modern China is an indispensable task to predicate the future of the country, but it is necessary to firstly recall when China changed its course towards reform and openingup. With the 1978 debate on truth criterion in Chinese Communist Party(CCP), 
the "resolution on certain questions in the history of our party since the founding of the People's Republic of China" and the reevaluation of the Cultural Revolution, China has altered its interpretation of history each time it has made a major stragetic change.

What is present-day China's place in history, and where is it heading? The answer to this globally concerned question is strongly requested by Chinese historians. In the past 30 years, Chinese historical research has continued to seek answers in accordance with the dramatically changing Chinese society. Now, when elements of uncertainty are greatly increasing, have China's historians found an abundantly persuasive answer?

There has been a fascinating data analysis performed by a researcher at the Institute of Modern History at the Chinese Academy of Social Sciences. ${ }^{1}$ When ranking all the keywords in papers published in "Modern Chinese History Studies" (the journal edited by the Institute of Modern History at the Chinese Academy of Social Sciences) in the decade from 1998-2007 by number of times used, the top ten rankings were a list of proper nouns: Chiang Kai-shek (18 times), Sun Yat-sen (17 times), Kang Youwei (17 times), the Kuomintang (14 times), the history of the Taiping Rebellion (13 times), Liang Qichao (11 times), Hu Shih (10 times), nationalism (9 times), Zhang Zhidong (9 times), and the Nationalist Government ( 9 times). From these data, the fact that the intellectual interest of today's historical researchers is being drawn more to reform than the revolution, and more to the history of the Republic of China than to the history of the Communist Party. Meanwhile, the keywords "Mao Zedong" and "Communist Party of China," which would have been expected certainly to dominate the top positions of statistics from before reform, had respectively receded to the $19^{\text {th }}$ and $23^{\text {rd }}$ spots. These data are noteworthy for pointedly indicating that the study of modern Chinese history is shifting from a revolutionary history centered on the Communist Party to the history of modernization and the history of the Republic of China.

The pluralization of society is supported by the pluralization of academic study. "Pluralization" may indeed be the most appropriate expression for explaining the changes in the acadeic arena of historical study. The era when only Marxist historical materialism was used as the methodology for studying history and the revolutionary view of history dominated historical research has already passed. Many scholars have welcomed the current state in which the Marxist view of history is no longer absolute, where "after reform and opening, the Chinese world

\footnotetext{
${ }^{1}$ Hong Yang, "Cong 'Jindaishi yanjiu' kan jin shi'nianlai de zhongguo jindai shi yanjiu," [Analyzing modern history studies in China over the past decade by studying "Modern Chinese History Studies"] Jindaishi Yanjiu [Modern Chinese History Studies] (2009) 5, pp.71-72.
} 
of modern history scholarship greedily absorbed the theories and methods derived from the modern Western humanities and social sciences. As a result, the world of historical scholarship, which had been fettered by rigid ideology achieved unprecedented advances". ${ }^{2}$

Naturally, when released from fetters of Marxist ideology, the subjects of scholarly interest expanded and decentralized. Meanwhile, there were rising concerns that if a variety of historical events that had previously been out of the range of a revolutionary view of history were to enter the arena of historians, the forest of modern Chinese history would be missed for the trees. Historical theory, which had gone too far, would be ignored. One of the interests of historical scholarship in recent years has been rebuilding a theoretical framework for analyzing the entirety of modern Chinese history. Chinese scholars refer to this as the rebuild of "systematicness," and it does not necessarily have to be a Marxist view of history. However, this mindset holds it to be indispensable to holistically apprehend modern Chinese history within a highly persuasive theoretical system.

This study of history, which could only exist as an accessory of politics until the early 1980s, is retaking an independent ethos, if in an incomplete manner. Using "law" and "justice" as well as "constitutional government" and "revolution" as keywords, this paper aims to extract the awareness of the issues of historians and historical scholarship in China, and to shed some light on the future appearance of Chinese society as reflected therein.

\section{Law and Justice: The Debate over the Paradigm for Modern Chinese History}

The paper, "Modernization and History Textbooks" by Professor Yuan Weishi at Zhongshan University was published in Dongfang Wenhua in December 2002. This was the period in which Japan and China fiercely clashed over the history textbook issue and the problem of Yasukuni Shrine visits by Japanese prime ministers.

In the summer of 1982, the dispute of history interpretation in Japanese textbooks arose between the two countries, casting a shadow on the bilateral relationship and the emotions of the people. Later in 1997, a group was formed in Japan for a new history textbook, which was edited and published in 2001. Meanwhile, history related disputes occurred repeatedly between Japan and East

2 Tianhong Yang, "Xitongxing de queshi-Zhongguo jindaishi yanjiu xianzhuang zhi you," [Systematic deficiency: some concerns over Chinese modern history studies] Jindaishi Yanjiu [Modern Chinese History Studies] (2010) 2. 
Asian countries. Although the adoption rate for this textbook was low, China learned that the book by this group became a bestseller and was approved by the Japanese Ministry of Education. Thus, the perception that "Japanese people do not admit their history of invasion" spread among the Chinese people. As if to further add insult to injury, Japanese Prime Minister Junichiro Koizumi, who took office in April 2001, visited Yasukuni Shrine before the anniversary of the end of WWII, deteriorating the feelings of the Chinese people towards Japan. Since then, the history issue has lain between Japan and China as the most important issue affecting the bilateral relationship, which took a large step backwards as neither side could find any clues leading to a resolution.

It is not certain whether or not Yuan Weishi's paper was written with the history interpretation issue between Japan and China in mind. Even to historians' surprise, though Chinese public opinion has been barraging the Japanese version of history interpretation, it did not point out the problem of Japanese textbooks. Instead, it criticized Chinese textbooks for being manipulated for political ends and distorting historical facts. There is no doubt that Yuan Weishi, as a historian, aimed to search for historical truth in his paper. However, it could be inferred from a series of statements he made later that he wrote the paper more out of a sense of responsibility as an intellectual and opinion leader. Unexpectedly, the paper did not draw much attention at that time, though it included a strong message for history scholars and teachers, as well as the general public.

The paper came to be widely noticed in January 22, 2006, when it appeared on Bingdian Weekly (Freezing Point) published by China Youth Daily. China Youth Daily is an official publication by the Communist Youth League of China, and Bingdian Weekly is the popular weekly publication by the same group. The chief editor of Bingdian Weekly, Li Datong came across Yuan Weishi's paper by chance, and strongly resonated with the issue discussed. As a journalist, he recommended re-release of the paper to Yuan Weishi, who accepted this. As a result, the paper was re-printed in a national publication, though it did not stir much of a response when it was first published. As feared by those around Li Datong, the Central Propaganda Department of the Communist Youth League closed the publication of Bingdian Weekly immediately after this issue. Of course, the order also came from the Central Propaganda Department of the Communist Party of China.

However, the fact that a newspaper having such a wide readership was forced to stop publication caused significant reverberations from both China and abroad. The order to halt publication must have been made reluctantly as the Chinese government had been trying to improve its image of openness to the international society with the Beijing Olympics only two years away. The fact that the Central Propaganda Department nevertheless made this decision means that they must have thought that the paper fundamentally overturned the view of history that 
the Communist Party of China had taught to its people since the founding of the nation in 1949, casting doubts on the legitimacy of the communist administration. To summarize the official Chinese view of history: (1) For the 60 years after the Opium War, the Great Powers forced China into numerous unequal treaties. Its sovereignty and territory were taken through concessions in forms of leased lands, denial of customs autonomy, and consular jurisdiction. As a result, the country was changed from a feudal society to a semi-colonized, semi-feudal society. (2) Patriotic organizations and revolutionary parties repeated violent revolutions, but the invasion of imperialism and the autocracy of feudalism were finally ended by the new democratic revolution led by the Communist Party of China. (3) Through the building of a new China, the conditions for building a modern state were set in place, and Chinese modern history transitioned from an era of revolution to an era of instituting modernization. Essentially, the "modern history" up until 1949 was the history of "anti-imperialism and anti-feudalism," and the "contemporary history" from 1949 onwards has been the history of aiming for modernization. Also, the Communist Party played a central role in the modern history of "antiimperialism and anti-feudalism" as well as the contemporary history of "instituting modernization."

\section{The Transforming Evaluation of the Boxer Rebellion}

In response to this view of history, Yuan Weishi asserts that it is the change from a pre-modern society to a modern society that is the theme of the modern era in China. Just as the anti-imperialist, anti-feudal revolution is characterized in this way, the frequent revolutionary movements were also efforts for achieving a modern state. It goes without saying that a modern state is a prosperous, democratic, independent state with freedom based on the rule of law. To Yuan Weishi, reforms and revolutions leading to such a modern state are healthy. Conversely, destructive and violent actions divorced from "law" do not lead China towards a modern state, but instead bring about ignorance and calamity to the state and the society. Also, he cites the Boxer Rebellion as an exemplar of "a foolish undertaking that regarded modern civilization as an enemy, and blindly rejected foreigners and foreign cultures.

Today, there are also many other Chinese historians, who view the Boxer movement as "anti-civilization" violence. As history interpretation diversifies, it is not unusual to find research condemning the armed groups that appeared at the end of the 19th century in various regions as "mobs" instead of depicting them as anti-imperialist patriotic organizations. The evaluation of the leaders of the Boxers has also become much more severe. Traditionally, they have been considered to have patriotic ideals and anti-imperialist principles. But recently, they have come to be seen at best as conservative groups of people who were ardently consumed 
by an intense mentality of resistance to religion and technology from the West. In other words, in the eyes of many scholars, the Boxer movement no longer was an "anti-imperialist, anti-feudal patriotic movement," as written in textbooks. Rather, it was a resistance movement against modern civilization and extremely biased against the West after the Hundred Days' Reform. The Qing government and the Dowager Empress Cixi manipulated the conservative and xenophobic movement. ${ }^{3}$ The Boxer Rebellion was actually a historical event that reflected the "backwardness" of Chinese society. What interest scholars, therefore, is the cultural and historical factors in China that led to the event.

It must be noted that this view is not new in the social environment of recent years. After the Boxer Rebellion, in order to avoid the war responsibility of the Dowager Empress Cixi, who had declared war against the Great Powers, the Qing government decided to use the Boxers as a scapegoat, disparagingly calling them a "group of bandits." Meanwhile, from just after the Boxer Rebellion to the beginning of the Republic, the Boxers were known as "rabble rousers" among the intellectuals who sought "civilization," and were perceived to represent the "savageness" of Chinese society. The "stain" on Chinese history of the Boxer Rebellion was a topic that the intellectuals wished to avoid at all costs. ${ }^{4}$

However, the Boxers began to receive reevaluations in the second half of the 1920s, when the national revolution reached its climax in its attempt to restore sovereignty, and the Communist Party's anti-imperialist political agenda became a new trend of the time. Once the Communist revolutionary view of history became dominant particularly after the Anti-Japanese War and the Chinese Civil War, the historical sensibility of the intellectuals at the beginning of the 20th century faded, and the Boxer Rebellion became known as a patriotic, anti-imperialist, and antifeudal revolutionary movement.

It was after the 1980s when the modernizing view of history became mainstream in place of the revolutionary view of history that the Boxer Rebellion once again came to be considered a "blindly anti-foreign movement." In particular, amidst the overall repudiation and reflection on the Cultural Revolution, the similarities of "feudal ignorance" and "rebellions for a just cause" between the Boxers and the Cultural Revolution were noted. ${ }^{5}$ In a sense, the re-evaluation of the Boxers resulted from the blanket repudiation of the Cultural Revolution. It was also during this period that many studies taking the negative side of the Boxers

\footnotetext{
${ }^{3}$ Yong Ma, "Yihuetuan shi zenyang yundong qilai de," [How did the Boxers get mobilized] Baike Zhishi [Knowledge] (2008) 21.

${ }^{4}$ Ming Zhang, "Yihetuan, yige shiji de yinying he huati," [The Boxers: Shadow and topics for a century] Kan Lishi [Analysis of History] (2010) 5.

${ }^{5}$ Kimihiko Sato, Hyoten jiken to rekishi kyokasho ronso [The Hyoten Incident and the history textbook controversy] (The Duan Press, 2007), pp.92-5.
} 
started to be published in academic journals in the field of history. Yuan Weishi's paper can be considered a representative work reflecting these drastic fluctuations in Chinese politics, society, and academia from the 1980s onwards.

\section{History Textbooks unable to catch up to Historical Research}

The change in the evaluation of the Boxers represented a shift in the way that history is interpreted. That change occurred at the level of "historical research", but fell short to the "history education" level, at which state has the right to edit textbooks. The view that the Boxer Rebellion was an "anti-imperialist, antifeudal" revolutionary movement has remained intact ever since the founding of the country in history textbooks and at school education. The way that history is documented in textbooks represents official stance of the government. It has a decisive effect on the youths. Perhaps dissatisfaction regarding textbooks propelled Yuan Weishi's paper into the world.

In the paper, Yuan Weishi lists the following points as defect revolutionary views in history textbooks that have remained even after the reform and openingup policy.

First, the textbooks do not mention that the Boxers were a "foolish undertaking" that considered modern civilization to be the enemy, and blindly rejected foreigners and foreign culture. Yuan Weishi notes that "the Boxers destroyed power lines, schools, and railroads, burned Western goods, killed Westerners, and even killed those Chinese who had even the slightest connection to foreigners or foreign culture". He criticizes the statements in textbooks, saying, "The destructive actions of the Boxers came entirely from a hostile view of foreign things, and were not emergency measures adopted out of necessity to resist invaders."

Next, the textbooks also do not criticize the fact that the Boxers massacred innocent civilians and committed arson and looting. Based on the records in the Yihetuan Dang'an Shiliao Xubian (Sequel Historical Material to the Boxers Archives) edited by the First Historical Archives of China, Yuan Weishi confirms facts including that "during the Boxer Rebellion from June 24 to July 24, 1900, 321 foreigners were killed throughout the country, including 53 children. The number of Chinese adherents killed is uncountable. In Shanxi province alone, over 5700 Chinese Catholics were murdered." He argues that "those stubborn people who did not want to accept progressive things were all those who inherited the most backward, barbaric portions of traditional culture."

Yuan Weishi's third point is that the textbooks do not at all mention the disasters of modern China caused by the autocracy and tyranny of the Dowager Empress Cixi.

Based on the Boxer Protocol signed between China and the Great Powers 
after the Boxer Rebellion, China was to pay an indemnity of 450 million customs taels to the Great Powers. This was equivalent to roughly six years of government revenue at the time, adding tremendous fiscal burden to the Chinese government for the next 39 years of repayment period. In addition, with the excuse that large numbers of foreigners had been murdered, the Great Powers established a legation quarter, exercised the right to police this quarter, and forced China to allow the stationing of permanent guarding troops to protect the legations. Furthermore, the Qing government was forced to approve the occupation of important locations from the capital of Beijing to the coast. The actions of the Boxers gave an opportunity to imperial Russia to occupy the northeast portion of China. A large number of Chinese people were killed by the Russian army during the occupation. Additionally, the British army invaded Tibet and occupied Lhasa, and Germany requested a lease on the shore of Lake of Dongting and Poyang. It goes without saying that the imperialist countries that invaded China should be criticized, but it cannot be denied that the autocracy of the Qing government and the brutality of the Boxers are important factors that caused an enormous loss of China's interests.

The final point that Yuan Weishi notes is that the application of historical documents in China's history textbooks is extremely sloppy. As an example, the "Boxer ballad" that is mentioned in the textbooks did not actually exist, and was created by later generations for political purposes. Yuan Weishi expounds that the use of such uncertain sources as "historical documents" in textbooks instills a revolutionary view of history among young people. This reminds him of the Cultural Revolution, which raised a large number of "revolutionary youths."

Overall, Yuan Weishi is critical about the Boxers, saying that even if they really did bring about a tremendous achievement of "supporting the Qing and destroying the foreigners," this cannot compensate for their anti-civilization and inhuman mistakes. In this case, what would the Boxers be when viewed from the perspective of China's transformation to a modern state? According to Yuan Weishi, after the failure of the Hundred Days' Reform that began to gain awareness of constitutional government and freedom, the Boxer Rebellion was nothing but a historical phenomenon of the climax of reactionary countercurrents opposing reforms and holding fast to tradition,

Certainly, Yuan Weishi's evaluation of the Boxers and interpretation of modern Chinese history is not unique to him. Numerous scholars of modern history have asserted this line of views since the $1980 \mathrm{~s},{ }^{6}$ and many publications criticizing the "feudal ignorance" of the Boxers had already been published before Yuan Weishi's paper was released.

\footnotetext{
${ }^{6}$ Kimihiko Sato, Hyoten jiken to rekishi kyokasho ronso [The Hyoten Incident and the history textbook controversy] (The Duan Press, 2007), pp.92-5.
} 


\section{Historical Interpretation as a Contemporary Interest}

The interests of Yuan Weishi, who noted defects in Chinese history textbooks, lay not in "historical truth" itself, but in the "contemporary era." Like many intellectuals, Yuan Weishi as a historian and a philosopher has indicated a strong interest in the shift from the traditional to the modern in Chinese society. He has repeatedly asserted that if a modern society is guaranteed by institutions based on the rule of law, establishing a mentality of the rule of law among the Chinese people is the most important task.

It is a commonly used means in history scholarship in China to seek the answer for modern questions through the interpretation of history. The frequent use of "historiography by inference" during the Cultural Revolution is still a fresh memory. It cannot be denied that these methods invited fallacies in historical interpretation, and brought about the stagnation of history scholarship. However, many historians recognize that the present-day task for Chinese historical scholarship, which has been turned into a political means over the long period of thirty years, is to aim to be de-politicized and de-ideologized, while providing wisdom for modern statebuilding. Led by such an understanding, some historians have adopted a methodology of finding a prescription for present-day problems through interpretation of historical facts by discovering in history the problems that contemporary China is experiencing. Yuan Weishi is one of these historians. He has closely paid attention to the question why the rule of law has shown no sign of taking hold in China during the past century ever since the Chinese Revolution. He concludes that the interpretation of the Second Opium War and the Boxer Rebellion, and history education based on that interpretation are the most fundamental reasons for the delayed modernization of the mentality of the Chinese people.

For example, the general statement in the history textbooks about the cause for the outbreak of the Second Opium War in 1856 is as follows. A French Catholic priest committed an "illegal act" in Guangxi Province and was executed by a local official. The French used this as a pretext to collude with Great Britain to invade China. To clarify the facts, Yuan Weishi looks to the Treaty of Whampoa signed between France and China in 1844. He explains that the killing of the priest by the acting governor of Xilin county, Zhang Mingfeng, violated China's treaty obligation to return arrested French citizens to the consulate. On the grounds of this interpretation, he instead blamed the "illegal" act of the Chinese side. That is, "from the legal perspective of procedural justice, there is no doubt that what the Chinese side did cannot be justified."7

\footnotetext{
7 Weishi Yuan, Chugoku no rekishi kyokasho mondai: Hyoten jiken no kiroku to hansei [History textbook issues in China: records and reflection of the Hyoten Incident] (The Duan
} 


\section{From a Revolutionary View of History to a Modernizing View of History}

There are at least two critical points for us to understand the Second Opium War and the Boxer Rebellion. The first is about the modern Chinese history. As the positivist approach to history regains its status after the 1980 s, some historians have noted an insufficiency in the "revolutionary view of history," which had continued to be enshrined in a dominant position since the founding of the country. They claim that it is necessary to understand modern Chinese history through the "modernizing view of history." According to the "modernizing view of history," the anti-imperial, anti-feudal revolution was one way to modernize the country, but not the "central theme" of modern Chinese history. If freedom of the people, rule by law, democracy and protection of private property are the criteria for modern state, improvements and reforms without having to resort to revolution and war should also be evaluated as efforts to modernize the state. Modern history must be rewritten within the context of modernization. As such, the efforts for modernization starting from the latter half of the $19^{\text {th }}$ century have continued to the present day. Modernization in lieu of democracy, freedom and rule by law has remained to be the fundamental task since the end of the Qing period to the present day.

In contrast, the official view in the textbooks is a revolutionary one of "antiimperialism and anti-feudalism" as represented by Zhang Haipeng's article mentioned earlier. From the revolutionary view of history, China in the pre-1949 period was a semi-colonized state that was trampled upon by the Great Powers, while being a feudal state dominated by domestic reactionary forces. With the restoration of sovereignty beyond its control, China was not in an environment to modernize. As a result of a Communist-led revolution, sovereignty was restored, and China became a completely independent state able to seek for modernization. To describe the modern Chinese history until the founding of a new Chinese state as an "anti-imperial, anti-feudal" revolutionary one substantiates the inevitability and legitimacy of the Chinese Communist Party in modern Chinese history. Conversely, advocating a modernizing view and challenging the revolutionary one is tantamount to challenging the legitimacy of the Communist Party administration. On this point, Sato Kimihiko notes that "[historians with modernizing views] used historical proof to criticize political reality and history textbooks (nothing represents the government more than history textbooks). The urban intellectuals condemned modern history from an extremely Western modernist and modernization viewpoint. This certainly upset the Communists who believes that they seized power and build a new China by crawling about over the

Press, 2006), pp.53-54. 
yellow land and fighting bloody wars". 8

The second is the question of how to place contemporary China within modern history. According to the revolutionary view of history, the establishment of contemporary China was the fruit and boon of the anti-imperialist, anti-feudal revolution. It is true that in the Mao Zedong era until 1976, there were repeated mass movements such as the Campaign to Suppress Counterrevolutionaries, the Anti-Rightist Movement, and the Cultural Revolution. The shift from "revolution" to "instituting modernization" was neglected, bringing about tremendous disorder in the Chinese society. As a result, the process of Chinese modernization was greatly delayed. However, since 1978 China has turned to a policy of modernization in earnest. The economic growth of the subsequent 30 years is truly the fruit of institution of modernization led by the Communist Party. In this viewpoint, today's China is regarded positively.

On the other hand, in the understanding of the "modernizing view of history," the goal to become an independent state has indeed involved a large amount of task in modern Chinese history. Yet, China lost its independence and sovereignty as a result of denying Western civilization. National elites poisoned by the ideology of the imperial court rejected the modern treaty system. ${ }^{9}$ Consequently, the shortcut for restoring independence and sovereignty was to accept Western civilization and establish democracy and rule of law in China. As a result, although it is true that independence was achieved by means of a revolution, if China had actively accepted Western civilization and tried to achieve independence through democracy and a constitutional government, it could have been possible to realize a modern state without the tremendous sacrifice paid by the Chinese people. The most important thing is that some severe social problems that are currently troubling Chinese society arose due to lack of democracy and rule of law. In other words, sanctification of the revolution made China unable to attain its goal of achieving democracy and rule of law since the second half of the $19^{\text {th }}$ century. The problems that China has faced since the latter half of the $19^{\text {th }}$ century still remain unresolved. Thus, being left behind in the international society, China has idled for over a hundred years. In short, China today is regarded negatively.

Thus, which viewpoint we take to see Chinese modern history is not merely a question of historical interpretation. It has much to do with the issues of how to evaluate the Chinese Communist Party's legitimacy and the PRC under the rule of the CCP. These are very much contemporary questions. To intellectuals who sympathize with Yuan Weishi, shifting China from the revolutionary view of

\footnotetext{
8 Kimihiko Sato, Hyoten jiken to rekishi kyokasho ronso [The Hyoten Incident and the history textbook controversy] (The Duan Press, 2007), p.94.

9 Weishi Yuan, "Yuan mingyuan: Kunan laizi yu luohou he fengbi" [The Imperial Gardens: teh plight comes from backwardness and isolation] (2010) http://blog.sina.com.cn/yuanweishi.
} 
history that considers "justice" to be supreme to the modernizing view of history based on the "rule of law" is indeed the first step for turning China into a modern constitutional state.

\section{Constitutional Government and Revolution: Perspectives on the Chinese Revolution}

\section{How to understand the Chinese Revolution}

In October 9, 2011, a gathering was held in Beijing to commemorate the $100^{\text {th }}$ anniversary of the Chinese Revolution. As the evaluation of the Chinese Revolution within modern Chinese history significantly transforms in academia in recent years, the opinion of the party and the government was closely watched. The speech by President Hu Jintao generally followed the traditional official view, but differed in a number of points from the speech by President Jiang Zemin at the gathering 10 years earlier commemorating the $90^{\text {th }}$ anniversary. He repeated the basic understanding that "the Chinese Revolution toppled the rule of the Qing dynasty, and put the final nail in the coffin of thousands of years of autocratic monarchical rule." But there was the new wording that "the revolution spread the notions of democracy and the republic within China, and significantly promoted transformation in the Chinese society". ${ }^{10}$ Although it is unwise to pry too deeply into statements by China's leaders, the expressions "the notions of democracy and the republic" and "transformation in the Chinese society" are based on the research results of history scholarship of recent years. It reflects the understanding that contemporary China is an extension of the social changes since the Chinese Revolution. President Hu's speech caused a gut feeling that the modern view of history, which had only emphasized "revolution" and undervalued "transformation," was beginning to subtly change.

In contrast to these minor changes at the official side of the government, the depiction of the Chinese Revolution by intellectuals changed quite markedly.

As it is clear from the history of the Chinese Revolution studies, the revolution has been manipulated for political purposes for a long period of time. To the Kuomintang as well as the Communist Party, the Chinese Revolution was merely an expedient to claim their own legitimacy to rule. ${ }^{11}$ According to Kuomintang's view of the history, among the numerous political groups since the end of the Qing dynasty, only the Kuomintang of China, which derived from the Revive China

\footnotetext{
10 People 's Daily 10 Oct 2001; People's Daily 10 Oct 2011.

${ }^{11}$ Ying Zhu, "Bainian yilai de xinhai geming lishi xushi," [Discription of the history of the Xinhai Revolution in the past century] Dushu, Shenghuo dushu xinzhi san lian shudian [Readers: SDX Joint Publishing Company] (2011), 387.
} 
Society, was the "legitimate" organization. Also, the only leader of the revolution was Sun Yat-sen. Thus, in order to prove the legitimacy of the Kuomintang, its accomplishments along with those of Sun Yat-sen were emphasized, and other historical events and personages were deliberately trivialized, and even erased from history.

In contrast, the Communist Party has depicted a different picture of the Chinese Revolution since the 1960s. Sun Yat-sen was elevated as a "bourgeois-democratic revolutionary", and the Chinese Revolution was defined as "an anti-imperial, anti-feudal bourgeois-democratic revolution." According to this line, though the Chinese Revolution toppled the Qing dynasty and established the Republic of China, it was an incomplete old democratic revolution. It was the new democratic revolution led by the Communist Party that succeeded in the anti-imperialist, antifeudal revolution. In this sense, the new democratic revolution achieved the tasks left behind by the Chinese Revolution. Consequently, it is the Communist Party that is the legitimate successor to Sun Yat-sen's revolution.

Thus, the competition for legitimacy between the Kuomintang and the Communist Party determined the nature of research of the Chinese Revolution until the 1980s. The 1990s saw an increase of people's interest in the possibility of and roadmap for "Chinese democratization". It was against this backdrop that the study of the Chinese Revolution became associated with civil rights and constitutional government in modern China. Some researchers argue that the revolution was successful not only because the revolutionaries under Sun Yatsen made effort, but also the constitutionalists also played their indispensible part in cooperation with the revolutionaries. The study of the Chinese Revolution suddenly came to embrace many different views. Some even criticized the revolution, focusing on its negative impacts on the constitutional government of China. In short, the Chinese intellectuals are no longer solely interested in the traditional view of history that emphasizes the competition for legitimacy. Rather, they have begun to shift their research interest to whether the Chinese Revolution was able to contribute to Chinese politics, social progress, and the formation of constitutional government in China.

\section{The Debate over the Cause of the Revolution}

There are three different aspects in the interest of research of the Chinese Revolution. The first is about the cause of the revolution, is significantly related to the understanding of the "new politics" promoted by the Dowager Empress Cixi.

During China's modern history, different opportunities have appeared for realizing constitutional government. In addition to the period around the Chinese Revolution, people paid attention to the periods when the Kuomintang and the Communist Party negotiated with each other after the end of the Sino-Japanese 
War, and the era immediately after the Communist Party founded the country after the civil war. These were the times when opportunities arose for a constitutional government. However, in recent years, scholars came to recognize that the most crucial period that determined the future path of China was the two decades between the new government at the end of the Qing period and the beginning of the republic.

This recognition originates from a simple question. A series of reforms had been carried out in order to realize the constitutional government before the Chinese Revolution. Why did the revolution occur just when people started to see hope for a government that reflects the general people's will? One hypothesis regarding this question is that "the new government caused the revolution."

According to the "revolutionary view of history," the hypothesis is based on the following points. After the Boxer Rebellion, the Qing government carried out a variety of reforms in the areas of education, military, and economy, and even indicated a will towards a constitutional government. However, it did so in order to maintain its reactionary governance instead of out of the purpose of achieving a constitution based democratic government. Therefore, it was only inevitable for the Chinese Revolution to break out in order to topple this reactionary regime.

However, recent history scholars do not believe in this revolutionary point of view of the history. It was not the rulers of the Qing Dynasty who attempted to maintain the power that caused the revolution. Rather, the revolution broke out because the government failed to grasp the will of the people. ${ }^{12}$ The will of the people was represented by three new political forces that emerged during the period of the new government. "The first was the popular revolutionary force that had been latent outside the regime. The second was the provincial scholarbureaucrats and elites at the periphery of the regime. The third was the potent Beiyang faction inside of the regime. These three grew stronger during the period of the new government, with ambitions to influence politics at the center". ${ }^{13}$ However, the reforms of the Qing government did not satisfy the majority faction of the scholar-bureaucrats and elites. While the Hans and the Mongolians secured only five and one minister position (s) respectively at the newly established government, the Manchurians had seven. The dissatisfaction of Han people could be one of the causes for the revolution.

\footnotetext{
12 Yi Lei, "Zongti xing shibai yu geming qiyuan," [Fundamental failure and the origin of the revolution] Dushu, Shenghuo dushu xinzhi san lian shudian [Readers:SDX Joint Publishing Company] (2011) 391.

${ }^{13} \mathrm{Jilin} \mathrm{Xu}$, Kakumei ga kensei wo ryoga shita no ha naze ka-Shingai kakumei zengo ni okeru, seido henyo no bunkiten [How did the revolution overwhelm the constitutional governance: institutional transition around Xinhai Revolution] Shingai kakumei 100 shunen kinen kokusai symposium Kobe kaigi, Kaigi shiryo [Meeting Documents from the International Cenntenial Symposium for the Xinhai Revolution at Kobe] (2011).
} 
Also, the stance of the reforms of the Qing government amplified the distrust of the constitutionalists. The Qinding Xianfa Dagang (Imperial Decree on the Outline of the Constitution) promulgated in 1908 gave the emperor much more power than the Meiji Constitution did at the expense of the people, thereby fomenting suspicion of the reformists all over country. "The constitutionalists (most of whom were local elites) held large petition campaigns for four times between January and November 1901. Regardless of this nation-wide momentum, the dynasty did not compromise at all and held on to power tenaciously. It rejected to convene national congress and implement the constitution, while harshly suppressed these campaigns". ${ }^{14}$ Trust between the government and the state was jeopardized because the constitutionalists and others did not regard the dynasty was sincere.

The distrust had in turn brought the very legitimacy of the government into question. The revolution was successful without having many people to shed their blood, because the constitutionalists came to support the revolutionaries once the revolution broke out. As such, historians came to believe that the advent of the Chinese Revolution was brought by the lack of trust between the government and the people. One example is Xu Jilin of East China Normal University. He maintains, "the rulers at the end of the Qing period did not have the courage to open up the administration while pressing ahead with the new government. As the pressure for political participation rises, the government reversed its policy to maintain the political power by staffing imperial family members in the cabinet. This infuriated the political forces that had already been mobilized. In addition to anti-Manchuria forces in the society, now even the usually dovish gentries and the Beijing faction at the center rejected the policy line and stared to demand for rapid changes". ${ }^{15}$ Zhang Ming at Renmin University of China states, "it is not the reforms that caused the Chinese Revolution. Rather, it is that the anti-reform government behind a reformist façade that caused the revolution". ${ }^{16}$

\section{Differing Evaluations of the late Qing Reforms}

In contrast to these studies that regard the incomplete reform and distrust between

\footnotetext{
${ }^{14}$ Shen Lei, "Zongti xing shibai yu geming qiyuan," [Fundamental failure and the origin of the revolution] Dushu, Shenghuo dushu xinzhi san lian shudian [Readers: SDX Joint Publishing Company] (2011) 391, p.11.

15 Jilin Xu, Kakumei ga kensei wo ryoga shita no ha naze ka-Shingai kakumei zengo ni okeru, seido henyo no bunkiten [How did the revolution overwhelm the constitutional governance: institutional transition around Xinhai Revolution] Shingai kakumei 100 shunen kinen kokusai symposium Kobe kaigi, Kaigi shiryo [Meeting Documents from the International Cenntenial Symposium for the Xinhai Revolution at Kobe] (2011).

16 Ming Zhang, "Xinzheng yu xinhai geming," [The new government and Xinhai Revolution] Dushu, Shenghuo dushu xinzhi san lian shudian [Readers: SDX Joint Publishing Company] (2011) 391 .
} 
the government and the people as the cause for the revolution, other scholars highly evaluate the reform at the end of the Qing dynasty. Instead of analyzing the aims of the new government, they pay attention to its impact against the historical backdrop. As early as ten years ago, some scholars argue, "the subjective aim of the Qing government was to maintain the prerogative of governing. But any government of course has the right to carry out reforms. It is important that the preparatory draft of the constitution significantly imitated the Meiji Constitution. The outline of the constitution shows that it manifests the principle of civilian rule as those constitutions of capitalist states do. This is a substantive progress for China, granted that it had sustained autocracy for millennia. This event merits attention in China's history of quest for political modernization." ${ }^{17}$ Recently, Yuan Weishi highly evaluated the series of events, arguing, "although there is no doubt that the preliminary constitution of the late Qing was a plan for it to stay in power, it brought significant impact in China's modern history." 18 In short, the Qing government did not stick to a reactionary line. Rather, it set China on the track of modernization by adapting to the tide of the time and pushed through the reforms.

When historians such as Yuan Weishi evaluate reforms of the late Qing dynasty, they first cite the abolition of the imperial examinations. This system for bureaucratic recruitment that had continued for over a thousand years since the Sui dynasty abruptly ended in 1905 without much confusion. Meanwhile, new academies were established, and Western educational system and contents were introduced to China. The reform of the educational environment was useful in preparing the groundwork for modernization. The Qing government secured help from great powers, including Japan, to send numerous students to study abroad. The government exerted efforts to train human resources with an international perspective while compensating for the lack of schools and educators in China that resulted from the drastic reforms.

Also, the reform ended China's traditional legal system, and introduced the continental law from Europe. This was the first step toward an independent judiciary drew attention from historians, because it was a symbol of modernization.

"Shangyu" (Decree) promulgated in 1908 stipulated that in the following nine years a constitution was to be prepared so as to be formulated in 1916 . Accordingly, conference boards were instituted in 1909 as preparatory bodies for

17 Zhou, Yan and Li, Dan, "Qingmo xinzheng yu zhongguo jindaihua" [New ruling system at the end of Qing Dynasty and Chinese modernization] Lishi Dang'an [Historical Documents] (2010) 2.

${ }^{18}$ Weishi Yuan, "Xinhai geming de lishi ju bian yu deshi," [Historical change and cost-andbenefit of the Xinhai Revolution] Shenzhen Tequ Bao [Shenzhen Special District News] (11 October 2011a). 
provincial legislatures, and the Zizhengyuan (Political Committee) was instituted in 1910 as the preparatory body for a national legislature, setting China on the track towards the founding of national congress.

Regional autonomy systems also began to emerge in Northeast, Shanghai and Tianjin disputes and conflict of interests in the society. Regional autonomous institutions were created based on the principle of separation of powers.

Recently, some historians argue that if China continued this line of reform, it may have had been able to avoid the chaos in the modern era. The rule of law and constitutional governance would have taken hold in China earlier. They regard the Chinese Revolution as an "extreme revolution," and Sun Yat-sen an "extremist." So, they assert that the Chinese Revolution interrupted the progress towards a constitutional government in China. ${ }^{19}$

Essentially, the image of the Chinese Revolution that emerged as a result of search for the causes of the revolution is as follows. The Qing government lost people's trust because it did not seriously want a constitutional government. Without popular support, the Qing government turned its erstwhile ally of the constitutionalists into an enemy, who cooperated with the revolutionaries and successfully carried the revolution in no time. Meanwhile, the Chinese Revolution also interrupted the momentum towards a constitutional government that had started in the late Qing period, leaving the task to contemporary China.

\section{Different Interpretations of the Achievements of the Chinese Revolution}

Another research interest in the Chinese Revolution studies is about how scholars interpret the revolution's result. Earlier conventional interpretations have it that the foremost achievement of the revolution is that it ended the imperial rule that lasted for over two thousand years. However, as people's interest toward the constitutional government grows since the 1990s, they also come to understand the result of the revolution very differently. For instance, Yuan Weishi argues that the mere fact that the revolution overthrew the imperial rule is not that significant. ${ }^{20}$ Indeed, many countries that retained imperial ruling had successfully realized constitutional governance and/or democracy. Rather, the historical significance of the Chinese Revolution could be summarized in the following two points.

First, as a result of the revolution, a modern state system of separation of

\footnotetext{
${ }^{19}$ Yi Lei, "Zongti xing shibai yu geming qiyuan," [Fundamental failure and the origin of the revolution] Dushu, Shenghuo dushu xinzhi san lian shudian [Readers: SDX Joint Publishing Company] (2011) 391, p.4.

${ }^{20}$ Weishi Yuan, (2011b) "Xinhai geming yu bainian xianzheng," [Xinhai Revolution and a hundred year of constitutional government] Zhongguo Pinglun Yuekan Wangluoban [Chinese Forum Monthly Internet Edition] (2011b). http://www.chinareviewnews.com/crn-we-bapp/ $\mathrm{mag} / \mathrm{docDetail} / \mathrm{jsp}$ ?coluid=10\&docid=101859951\&page.
} 
powers appeared at once. After the revolution, the parliament and independent judicial and executive authority were established. Efforts as such had been partially made all over the country.

Second, the people gained "freedom". Freedom of speech, association and academic study were guaranteed, and an unprecedented atmosphere of activism and freedom flooded the whole country.

However, these fruits from the Chinese Revolution did not last for long. Indeed, this is the third research interest in the Chinese Revolution. The question is why did the attempt to create a constitutional government during the early years of the republic after the revolution ultimately ended in failure? Xu Jilin has sought the answer to this in the struggle for power among the post-revolutionary factions and the neglect of the rule of law. After the revolution, the Beiyang forces from within, the gentry and elites at the periphery, and the revolutionaries outside of the regime focused on strengthening their own power. "Neither the Kuomintang nor the Progressive Party was interested in the deliberations and compromises for establishing a new constitution and new institutions for the republic. They were preoccupied with interparty political struggles of attacking other forces while expanding their own power bases". ${ }^{21}$ The obsession for power resulted in neglect of law. Even struggles that could be solved through legitimate competitions and legal methods within the system ended in violent "revolution." The "Second Revolution" was such typical example. After the assassination of Song Jiaoren, "the Revolutionary party held blind faith in revolution and violence. They took the first move in demolishing the laws and caused the Second Revolution. As a result, they were not only completely defeated due to their lack of power, but also lost the moral support of the people" (ibid.). In addition to all the political factions, now even popular sentiment lost faith in the rule of law and constitutional government. As noted by $\mathrm{Xu}$ Jilin, the principle behind politics in the early years of the republic was not about "lawful" or "unlawful" but "virtuous" or "wicked."

Regarding the causes of such a phenomenon, Yuan Weishi explains that after the Chinese Revolution, the Kuomintang neglected to shift from a revolutionary organization to a democratic political party. According to Yuan, the majority of Kuomintang members who gained seats in the first national election had almost no understanding of the rule of law and popular sovereignty, and they forced their own wills onto others on a daily basis. Also, the "Provisional Constitution of the Republic of China" was not established based on legal procedures, and included

\footnotetext{
${ }^{21} \mathrm{Jilin} \mathrm{Xu}$, Kakumei ga kensei wo ryoga shita no ha naze ka-Shingai kakumei zengo ni okeru, seido henyo no bunkiten [How did the revolution overwhelm the constitutional governance: institutional transition around Xinhai Revolution] Shingai kakumei 100 shunen kinen kokusai symposium Kobe kaigi, Kaigi shiryo [Meeting Documents from the International Cenntenial Symposium for the Xinhai Revolution at Kobe] (2011).
} 
many defects. ${ }^{22}$

As seen above, within the new developments in the study of the Chinese Revolution in recent years, we can clearly identify two keywords of "constitutionalism" and "reform." They replaced "autocracy" and "revolution," which had previously been indispensable in the study of modern Chinese history. It is a fact in modern history that a constitutional government was sought via "reform" in lieu of "revolution", which could cause turmoil. This fact has become the most watched historical subject for contemporary Chinese historians. $\mathrm{Xu}$ Jilin's following comments are interesting:

"After the Chinese Revolution, wars continued, and revolutions repeated one after another. An overbearing authority was established at the center each time unity was achieved. There was never a constitutional government that guaranteed the long-term stability of the state. In this sense, the Chinese Revolution was truly the beginning of the $20^{\text {th }}$ century China. Even today after 100 years of the revolution, China still inherits the complicated legacy left behind by history". ${ }^{23}$

\section{Conclusion: The Near Future of Views of History}

The diversification in lifestyle and sense of value has also caused diverging views of history. How modern Chinese history is documented is deeply related with the way the history of the Republic of China is described. Yet, research of the history of the Republic of China on the mainland has just begun. Although plans for studying the history of the Republic were proposed in 1956 and 1971, they did not materialize due to the effects of the Anti-Rightist Movement and the Cultural Revolution.

The first volume of Zhonghua Minguo Shi (History of the Republic of China), which was published in 1981 after the beginning of reform and open-up, was the first publication since China's establishment that studied the history of the Republic. The research project on the history of the Republic has been mainly carried out by the Institute of Modern History at the Chinese Academy of Social

\footnotetext{
${ }^{22}$ Weishi Yuan, (2011b) "Xinhai geming yu bainian xianzheng," [Xinhai Revolution and a hundred year of constitutional government] Zhongguo Pinglun Yuekan Wangluoban [Chinese Forum Monthly Internet Edition] (2011b). http://www.chinareviewnews.com/crn-we-bapp/ $\mathrm{mag} /$ docDetail/jsp?coluid=10\&docid=101859951\&page.

${ }^{23} \mathrm{Jilin} \mathrm{Xu}$, Kakumei ga kensei wo ryoga shia no ha naze ka-Shingai kakumei zengo ni okeru, seido henyo no bunkiten [How did the revolution overwhelm the constitutional governance: institutional transition around Xinhai Revolution] Shingai kakumei 100 shunen kinen kokusai symposium Kobe kaigi, Kaigi shiryo [Meeting Documents from the International Cenntenial Symposium for the Xinhai Revolution at Kobe] (2011).
} 
Sciences. Twelve volumes of Zhonghua Minguo Shi were published in 2011 when the project ended at the centennial of the Chinese Revolution. The study of the history of the Republic though is extremely insufficient, given the fact that the Republic was an entire era in the 1911 to 1949 period.

In the 40-year history of the Republic, the Kuomintang was at the center of the regime. The preceding Beiyang government and the subsequent Nanjing government were central governments representing China. From the Chinese Communist Party's perspective, this era was only one part of the "history of revolution" in contemporary China. Recently, however, some historians have pointed out shortcomings in this kind of revolutionary view of history. They proposed a "view on history of the Republic of China" that brings the history of the Republic to the main stage. ${ }^{24}$ Yuan Weishi has continued to criticize the revolutionary view of history. He argues that the problem with the "revolutionary view of history" is that it has created tragedies in modern Chinese history by relentlessly establishing a "subject of revolution." More than 100 million "unnatural deaths" in each of the $19^{\text {th }}$ and the $20^{\text {th }}$ century resulted precisely from this view of history. The task in the study of modern Chinese history in the $21^{\text {st }}$ century lies in the construction of a "civilization-based view of history" that transcends the revolutionary view.

Can Chen Hongmin's view of the history of the Republic of China be a part of Yuan Weishi's "civilization-based view of history"? Just as the Chinese society in transition, China's modern history study is also exploring for new directions.

\section{References}

Chen, Hongmin, “"Minguo shiguan' yu zhonghua minguoshi xin xueke tixi de goujian" ["The Republic of China's view" and the constructon of a new academic discipline of the history of the Republic of China] Minguo Dang 'an [The Republic of China Archives] (2011) 1.

Lei, Yi, “Zongti xing shibai yu geming qiyuan," [Fundamental failure and the origin of the revolution] Dushu, Shenghuo dushu xinzhi san lian shudian [Readers: SDX Joint Publishing Company] (2011) 391.

Ma, Yong, "Yihuetuan shi zenyang yundong qilai de," [How did the Boxers get mobilized] Baike Zhishi [Knowledge] (2008) 21.

Sato, Kimihiko, Hyoten jiken to rekishi kyokasho ronso [The Hyoten Incident and

${ }^{24}$ Hongmin Chen, "'Minguo shiguan' yu zhonghua minguoshi xin xueke tixi de goujian" ["The Republic of China's view" and the constructon of a new academic discipline of the history of the Republic of China] Minguo Dang'an [The Republic of China Archives] (2011) 1. 
the history textbook controversy] (The Duan Press, 2007).

$\mathrm{Xu}$, Jilin, Kakumei ga kensei wo ryoga shia no ha naze ka-Shingai kakumei zengo ni okeru, seido henyo no bunkiten [How did the revolution overwhelm the constitutional governance: institutional transition around Xinhai Revolution] Shingai kakumei 100 shunen kinen kokusai symposium Kobe kaigi, Kaigi shiryo [Meeting Documents from the International Cenntenial Symposium for the Xinhai Revolution at Kobe] (2011).

Yang, Hong, “Cong 'Jindaishi yanjiu' kan jin shi'nianlai de zhongguo jindai shi yanjiu," [Analyzing modern history studies in China over the past decade by studying "Modern Chinese History Studies"] Jindaishi Yanjiu [Modern Chinese History Studies] (2009) 5.

Yang, Tianhong, "Xitongxing de queshi-Zhongguo jindaishi yanjiu xianzhuang zhi you," [Systematic deficiency: some concerns over Chinese modern history studies] Jindaishi Yanjiu [Modern Chinese History Studies] (2010) 2.

Yuan, Weishi, Chugoku no rekishi kyokasho mondai: Hyoten jiken no kiroku to hansei [History textbook issues in China: records and reflection of the Hyoten Incident] (The Duan Press, 2006).

Yuan, Weishi, "Yuan mingyuan: Kunan laizi yu luohou he fengbi" [The Imperial Gardens: teh plight comes from backwardness and isolation] (2010) http://blog. sina.com.cn/yuanweishi.

Yuan, Weishi, "Yuan Weishi bashi mushu, yao shuo zhen hua, shuo ziji de hua," Nandu Zhoukan, Vol. 479 (2010).

Yuan, Weishi, "Xinhai geming de lishi ju bian yu deshi," Shenzhen Tequ Bao (October 11, 2011).

Yuan, Weishi, "Xinhai geming yu bainian xianzheng," [Xinhai Revolution and a hundred year of constitutional government] Zhongguo Pinglun Yuekan Wangluoban [Chinese Forum Monthly Internet Edition] (2011).http://www. chinareviewnews.com/crn-we-bapp/mag/docDetail/jsp?coluid=10\&docid=1018 59951\&page.

Zhang, Ming, "Yihetuan, yige shiji de yinying he huati," [The Boxers: Shadow and topics for a century] Kan Lishi [Analysis of History] (2010) 5.

Zhang, Ming, "Xinzheng yu xinhai geming," [The new government and Xinhai Revolution] Dushu, Shenghuo dushu xinzhi san lian shudian [Readers: SDX Joint Publishing Company] (2011) 391.

Zhou, Yan and Li, Dan, "Qingmo xinzheng yu zhongguo jindaihua" [New ruling system at the end of Qing Dynasty and Chinese modernization] Lishi Dang'an [Historical Documents] (2010) 2.

Zhu, Ying, "Bainian yilai de xinhai geming lishi xushi," [Discription of the history of the Xinhai Revolution in the past century] Dushu, Shenghuo dushu xinzhi san lian shudian [Readers: SDX Joint Publishing Company] (2011) 387. 


\section{About the Author}

Jie LIU is Professor from the Faculty of Social Sciences, Waseda University, Japan. He received his Ph.D. degree from the University of Tokyo. His research interest includes modern history of Sino-Japanese Relations, Japanese foreign policy toward China in the Showa period and the history of International Relations in East Asia. His recent academic publication includes: Ima ajia wo dou kataruka [How do we analyze today's Asia?], in Manabu Arima, Ken'ichi Matsumoto, Takeshi Nakajima, Jie Liu, Sungsi Lee eds (Kyushu: Genshobo, 2011). 1945 nian de lishi renshi [Interpreting the history of 1945], in Jie Liu and Shin Kawashima eds (Beijing: Chinese Academy of Social Sciences, 2010). "Nichu wahei kousho to kairai seiken" [Sino-Japanese peace negotiation and the puppet regime], Iwanami Koza: Higashi Ajia Kingendai Tsushi [Iwanami lectures: Modern and Contemporary History of East Asia] (2011) 5, pp.262-84.“Ajia gendaika no kadai” [The tasks for Asia's modernization] Fukuoka Unesco (2010) 46."Nichu yuko to kindai nichu kankei shizou" [Sino-Japan friendship and the modern history of Sino-Japan relations ] Kikan Chugoku [China Quarterly] (2010) 103, pp.28-31 .Ajia kindai shi no naka no nihon" [Japan in Asian modern history] Ajia gaku no susume [Asian Studies] (2010) 3, pp.200-20.

Address: School of Social Science, Waseda University, 1-6-1 Nishi -waseda, Shinjuku-ku, Tokyo, 169-8050, Japan.

Email: liujie@waseda.jp 